ZOOLOGIA 31 (1): 51-62, February, 2014

http://dx.doi.org/10.1590/S1984-46702014000100007

\title{
Dimorphism and allometry of Systaltocerus platyrhinus and Hypselotropis prasinata (Coleoptera: Anthribidae)
}

\author{
Ingrid Mattos ${ }^{1}$, José Ricardo M. Mermudes ${ }^{1,3} \&$ Mauricio O. Moura²
}

\author{
${ }^{1}$ Laboratório de Entomologia, Departamento de Zoologia, Universidade Federal do Rio de Janeiro. Caixa Postal 68044, \\ 21941-971 Rio de Janeiro, RJ, Brazil. \\ 2 Departamento de Zoologia, Universidade Federal do Paraná. Caixa Postal 19020, 81531-980 Curitiba, PR, Brazil. \\ ${ }^{3}$ Corresponding author. E-mail: jrmermudes@gmail.com
}

\begin{abstract}
Males of sexually dimorphic anthribid species display structural modifications that suggest sexual selection. Polyphenism, which is expressed through morphological and behavioral novelties, is an important component of the evolutionary process of these beetles. In this study, we endeavored to ascertain the presence of variations in selected monomorphic traits, polyphenism in males, and variation in structures associated with sexual dimorphism and allometric patterns in two species: Systaltocerus platyrhynus Labram \& Imhoff, 1840 and Hypselotropis prasinata (Fahraeus, 1839). To that end, we used Principal Components Analysis (PCA) and Canonical Variate analysis (CVA) to statistically analyze 26 measurements of 91 specimens. The PCA discriminated three groups (females, major, and minor males) for S. platyrhinus, but only two groups (males and females) for $H$. prasinata. The same groups discriminated by the PCA for Systaltocerus were confirmed by the CVA analysis, indicating a highly significant variation separating the three groups. We also analyzed positive allometry with respect to prothorax length - independent variable by Reduced Major Axis (RMA). The allometric pattern indicated by most of the linear measurements was strong and corroborates a possible relationship between male polyphenism and the reproductive behavior of major and minor males. We believe that these patterns, in species that show both sexual dimorphism and male polyphenism, are associated with the behavior of defending the female during oviposition, performed by major males.
\end{abstract}

KEY WORDS. Anthribinae; morphometry; polyphenism; sexual dimorphism.

Male sexual dimorphism and polyphenism are ubiquitous in several species of Coleoptera (EMLEN et al. 2005, KaWANo 2006). These phenotypic differences are thought to be linked to fitness, since they influence reproductive success (EBERHARD \& Gutierez 1991, EMLen \& Nojhout 2000, EMlen 1994, 1996, 2008, EMlen et al. 2005, 2007, Kawano 2006). In insects, body size is an important phenotypic trait which often corresponds to adaptations (PossadAs et al. 2007). Some species of Coleoptera, for instance beetles with horns (e.g., Scarabaeidae, Dynastinae) and those with oversized mandibles (Cerambycidae, Prioninae, and Lucanidae) are model systems for studies on the evolution of sexual dimorphism and polyphenism (EBERHARD \& GUTIEREZ 1991, KaWano 2000, ShiokaWa \& IWAhashi 2000). Moreover, Anthribidae species show both sexual dimorphism and polyphenism (Mermudes 2002, Yoshitake \& KaWashima 2004).

Fungus weevils (Anthribidae: Curculionoidea) comprise about 370 genera and at least 3,900 species (SLIPINSK et al. 2011). Most species of Anthribinae have remarkable sexual dimorphism, particularly with respect to the size of the rostrum and antennae (Holloway 1982, Mermudes 2002, 2005, Mermudes \& Napp 2006). Anthribidae females have toothed sclerotized plates at the apex of the ovipositor, which bear conchoidal projections that are used to excavate plant tissues for oviposition. This behavior is unique and distinct among Curculionoidea, which use only the rostrum to dig plant tissues (Howden 1995).

Although sexual dimorphism in size and polyphenism in male size are widespread in Anthribinae (Mermudes 2002, 2005, Mermudes \& Napp 2006, Mermudes \& Mattos 2010), detailed information about it is only available for a few species (HollowaY 1982). Yoshitake \& Kawashima (2004) and Matsuo (2005) demonstrated that in large, intermediate, and small males of the Japanese fungus weevil Exechesops leucopis Jordan, 1928 the length of the eyestalks, which are associated with the agonistic behavior males use to protect females against other males on fruits of Styrax japonica Siebold \& Zuccarini (Styracaceae) differs. Large males that have more developed cephalic eyestalks win the disputes, indicating that sexual dimorphism and polyphenism in males are under sexual selection. However, smaller males (without developed eyestalks) can copulate in the absence of competition when females are not accompanied by larger males, which may partly explain the sneaky behavior of small males described by Yoshitake \& KaWASHima (2004). 
Agonist behavior in Anthribidae was also observed by Thompson (1963) and Howden (1992). Thompson reported that guarding males of Deuterocrates longicornis (Fabricius, 1781), a species from West Africa, defend females and engage in fights with other males using their mandibles. Howden (1992) recorded that males of Ptychoderes rugicollis Jordan, 1895, a Neotropical species, use their antennae and rostrum to protect females while they lay eggs on dead trees.

Considering the past detection of polyphenism in size in two species of Neotropical Anthribinae, Systaltocerus platyrhinus Labram \& Imhoff, 1840 (variations in the length and shape of the rostrum; Mermudes 2002) and Hypselotropis prasinata (Fahraeus, 1839) (different length of rostrum and antennae; Mermudes 2005, Mermudes \& Rodrigues 2010), we endeavored to determine whether there is variation in monomorphic characters (such as eyes, prothorax, and elytra), polyphenism in males, variation in sexually dimorphic structures (rostrum, antennae, and ventrites) and allometric patterns. This study contributes to the understanding of patterns of dimorphism and polyphenism in Anthribidae and evaluates structures that are likely to interfere with body size and/or with the relative size of other structures in the two species. However, whether agonistic interactions occur between males in those species remains unknown.

\section{MATERIAL AND METHODS}

In this study, we used a sample of 34 specimens ( 25 males and 9 females) of $S$. platyrhinus and 57 specimens ( 32 males and 25 females) of $H$. prasinata loaned from three collections (curators between parenthesis): MNRJ, Museu Nacional, Universidade Federal do Rio de Janeiro, Rio de Janeiro (M. Monné); AMCT, American Coleoptera Museum, San Antonio, Texas (J. Wappes); and DZUP, Coleção Padre Jesus S. Moure, Departamento de Zoologia, Universidade Federal do Paraná, Curitiba (L. Marinoni).

All individuals were measured using the standard imageanalysis software Moticam 1000, or in the case of elytral length, a digital caliper. Before each trait was measured, the specimen was oriented so that the trait of interest was as closely parallel to the plane of the objective lens as possible. The anatomical landmarks measured follow MERMUDES \& NAPP (2006) with some modifications. These modifications, defined in Table I, are based on characters that display variation among males and the sexes, independently of geographical locality. The 26 traits (measurements in millimeters) used were log-transformed (Table I and Figs 1-7).

Linear models and cluster analysis were performed in PAST version 2.0 (Hammer et al. 2001). Multivariate analyses (PCA and CVA) were run in vegan (OKSANEN et al. 2013) and Morph (Schlager 2013). Both packages were implemented in $\mathrm{R}$ (R Core Team 2013).

Variations in phenotypic traits between and within sexes were accessed through the coefficient of variation $(\mathrm{CV})$.

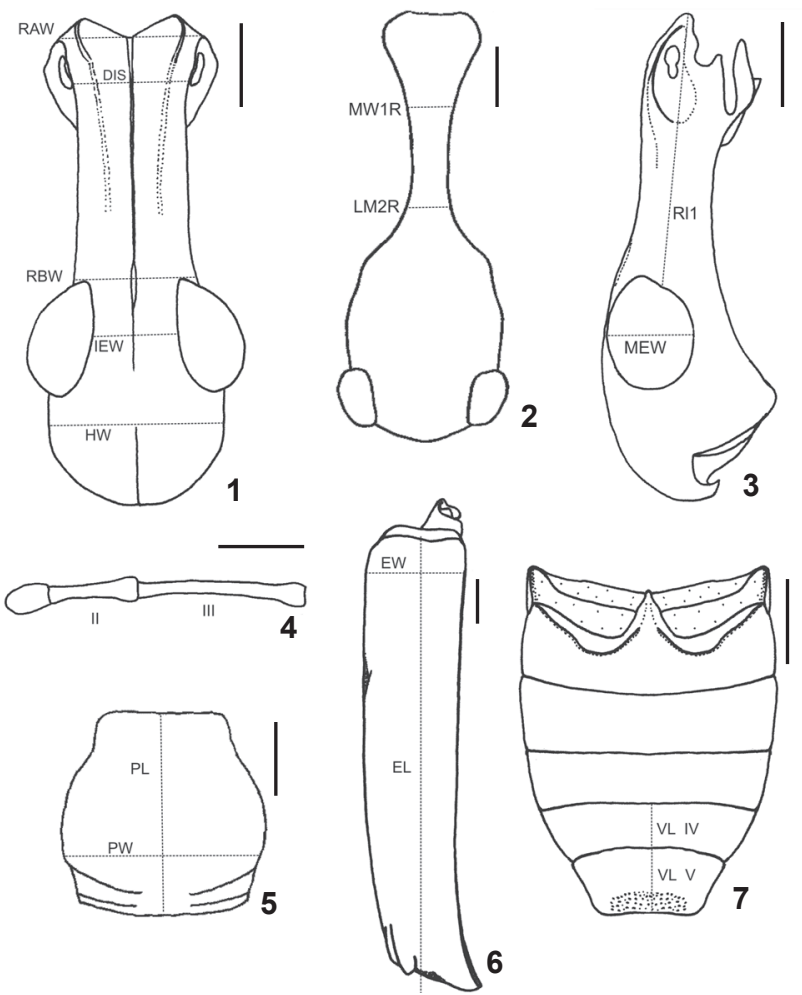

Figures 1-7. Diagram of the morphological traits measured: (1) Hypselotropis prasinata, head, dorsal; (2) Systaltocerus platyrhinus, head, frontal; (3-7) H. prasinata: (4) antennal segments I-III; (5) prothorax, dorsal; (6) elytron, dorsal; (7) abdomen, ventral. For abbreviations see Material and methods. Scale bars: $1 \mathrm{~mm}$.

A cluster analysis with Ward's methods (based on Euclidean distance) was carried out with 1,000 Bootstrap replicates (VALENTIN 2000). In this analysis, missing data were replaced by the column average. Additionally, a Principal Components Analysis (PCA) of the covariance-variance matrix of all variables was performed to reduce the dimension of the data matrix and to visualize possible differences among groups and characters that contributed the most to these differences. The first two component axes were then used as variables in a Canonical Variate Analysis (CVA) to test morphometric differences among groups.

The analyses were designed to test the relationship between body size (prothorax length $=$ PL) and all other variables. For this reason we used the allometric function $\mathrm{y}=\mathrm{ax}^{\mathrm{b}}$ (HuXLeY 1932, 1950). However, the data was log-transformed and expressed by: $\log \mathrm{y}=\log \mathrm{a}+\mathrm{b}(\log \mathrm{x})$, to fit a straight line (Gould 1966).

Body size (prothorax length $=$ PL) was used as a predictor variable and all other measurements were considered as response variables. However, in allometric studies, no variable 
Table I. Measurements obtained from each part of the body.

\begin{tabular}{|c|c|}
\hline Measures and abbreviation & Description \\
\hline Rostral length 1 (RL 1) & laterally between the anterior margin of the eye and the apex of the rostrum \\
\hline Apical width of rostrum (RAW) & dorsally at the apical margin of the rostrum \\
\hline Medial width 1 of rostrum (MW1R) & dorsally in the rostrum, only in Systaltocerus platyrhinus (modified from MeRMUDEs 2002) \\
\hline Medial width 2 of rostrum (MW2R) & dorsally in the rostrum, only in Systaltocerus platyrhinus (modified from MerMUDEs 2002) \\
\hline Head width (HW) & dorsally between the lateral margins of the head \\
\hline $\begin{array}{l}\text { Antennal segments, length = seven variables }(\mathrm{II}, \mathrm{III}, \mathrm{IV}, \mathrm{V}, \mathrm{VI} \text {, } \\
\text { VII, VIII) }\end{array}$ & along the midline of each segment \\
\hline \multicolumn{2}{|c|}{ Antennal segments of club, length $=$ three variables $(I X, X, X I)$ along the midline } \\
\hline Inter-eye width (IEW) & maximum distance measured between the inner eye margins \\
\hline Maximum eye width (MEW) & laterally between the outer eye margins \\
\hline Inter-scrobal distance (DIS) & maximum width between the inner margins \\
\hline Prothorax length (PL) & dorsally along the midline between the anterior and posterior margins \\
\hline Elytra length (EL) & dorsally between the anterior margin and the apical margin \\
\hline Elytra width (EW) & dorsally across the humeri \\
\hline Total body length $(T L)$ & sum of $\mathrm{PL}, \mathrm{EL}$, and RL 1 \\
\hline Ventrite length IV (VL IV) & along the midline \\
\hline Ventrite length V (VL V) & along the midline \\
\hline
\end{tabular}

can be considered independent (Gould 1966). Therefore, we decided to fit a model II regression, or Reduced Major Axis regression (RMA). This allows the combined variation of the two variables to be better described because there are associated errors in both.

The slope (b) of the model II regression is the allometric constant that expresses the relationship between two variables and it has been used as an indication of the allometric pattern (EMDEN 2008). Therefore, when b equals 0 there is no allometric relationship. However, when $b=1$ the relationship is isometric, $\mathrm{b}<1$ determines a negative allometry, and $\mathrm{b}>1$ describes positive allometry. The level of statistical significance was set at 0.05 in all analyzes.

\section{RESULTS}

The mean and standard deviation of all measurements were given in the Appendixes 1 and 2 . The amplitude of total body length (TL) and the coefficient of variation (CV) for $S$. platyrhinus and $H$. prasinata were summarized in Table II.

Sexual dimorphism. Males of $H$. prasinata (Fig. 8) are relatively larger than females (Fig. 9). Major males of $S$. platyrhinus (Fig. 10) are similar to females in size, whereas minor males (Fig. 11) of this species are smaller than their female counterparts (Fig. 12). Males and females of $H$. prasinata and $S$. platyrhinus did not differ in the following variables that correspond to monomorphic characters in both species: apical width of rostrum (RAW), basal width of rostrum (RBW), head width $(\mathrm{HW})$, prothorax length (PL), prothorax width (PW), elytra
Table II. Amplitude of the total length $(\mathrm{mm})$ for males and females of S. platyrhinus and $H$. prasinata $(n=34$, males $=25$ and females $=9)$.

\begin{tabular}{clcc}
\hline Species & Groups & CV & TL \\
\hline \multirow{2}{*}{ S. platyrhinus } & Males & 0.17 & $6.37-12.81$ \\
& Females & 0.12 & $8.22-11.36$ \\
S. platyrhinus & Major males & & $10.32-12.95$ \\
& Minor males & & $6.37-9.51$ \\
H. prasinata & Males & 0.15 & $10.86-19.60$ \\
& Females & 0.16 & $8.51-17.96$ \\
\hline
\end{tabular}

length (EL), elytra width (EW), inter-scrobal distance (DIS), and inter-eye width (IEW), as detailed in Appendix 1.

The independent $t$ test for sexual dimorphism of all variables is shown for the two species analyzed (Appendix 1). Males and females of the two species did not differ only in the maximum eye width (MEW). Based on the RMA results for $S$. platyrhinus (Table III), the elytral length and width did not show allometry. These results showed that all other structures are indicative of sexual dimorphism, as previously suggested by Holloway (1982) and Mermudes (2002).

Polyphenism in males. In S. platyrhynus, major and minor males differ significantly in almost all variables, with the exception of antennomeres VII, VIII, and IX and ventrite $\mathrm{V}$. The result of the independent $\mathrm{t}$ test for the polyphenism in males of the two species analyzed is shown in Table III. The presence of two groups of males in S. platyrhinus, relatively discrete in size, indicates size polyphenism (Table III and Ap- 


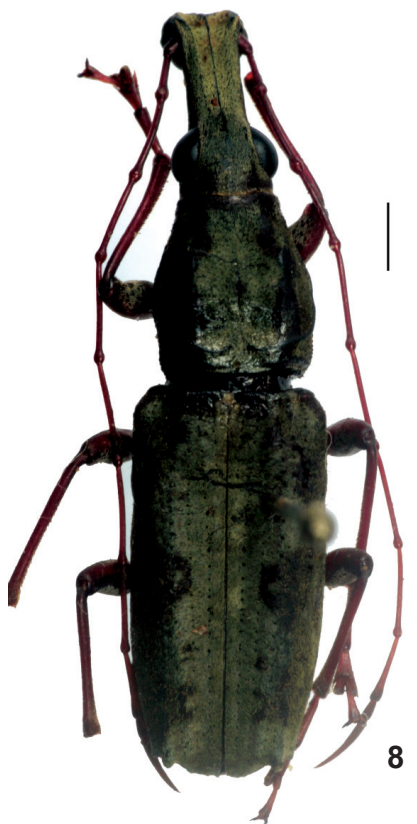

8

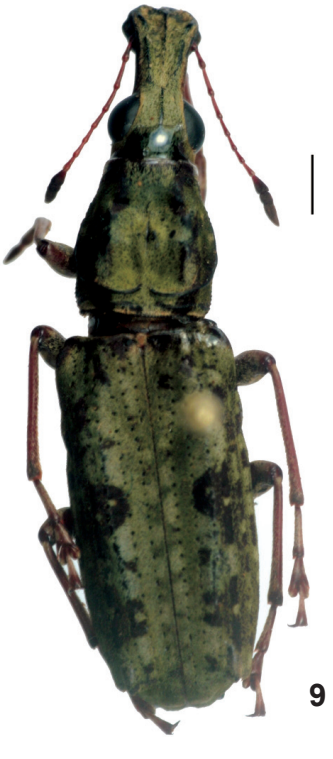

9

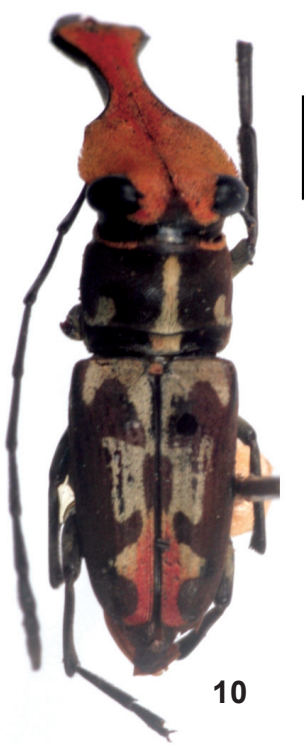

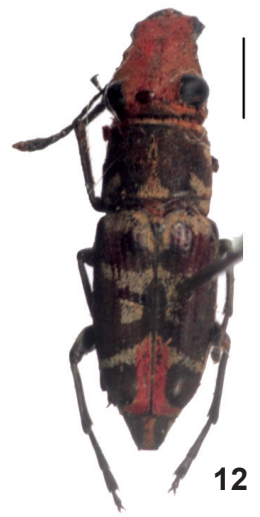

Figures 8-12. Dorsal habitus. (8-9) Hypselotropis prasinata: (8) male; (9) female. (10-12) Systaltocerus platyrhynus: (10) major male; (11) minor male; (12) female. Scale bar $=2 \mathrm{~mm}$.

pendix 2). In $H$. prasinata, although there is no evidence of major and minor males, we found intermediate males, suggesting a continuous variation in size (Table IV). Therefore, there were no discrete groups, rejecting the hypothesis of size polyphenism for $H$. prasinata males.

Multivariate analysis. Cluster Analyses with the Ward's Method, considered very efficient (VALENTIN 2000), identified different groups for each species analyzed. Bootstrap support values for these groups are shown within parentheses: three groups found for S. platyrhinus (Fig. 13): major males (76), minor males (75), and females (99); and two for $H$. prasinata (Fig. 14): males (respectively 29, 23) and females (74).

The Principal Components Analysis (PCA) indicated that size has a greater influence on the identification of groups (major males, minor males, and females) of S. platyrhynus (Table $\mathrm{V}$ and Fig. 15). The separation of the groups was evident by the analysis of the axes of components 1 and 2, which explain more than $80 \%$ of total variance. In the first axis (PC1), two groups were identified: males and females. The second axis (PC2) shows the separation between major and minor males. For $H$. prasinata, the principal components analysis indicated that size contributes to the differentiation of groups (Table V). However, there is no evidence of polyphenism in males (Fig. 16). The first and second components explained $87 \%$ of total evidence.

Canonical Variate Analysis (CVA), together with MANOVA, confirmed that there are three different morphotypes in $S$. platyrhynus (MANOVA CVA: Wilks' Lambda $=0.000194$; $\mathrm{df1}=$ $50 ;$ df2 $=14 ; \mathrm{F}=19.82 ; \mathrm{p}<0.0001$ ) with correct allocation of specimens exceeding 90\%. The separation of groups in $S$. platyrhynus (Fig. 17) was evident through the first two axes, of which the first $\mathrm{CV}$ provided information for the separation of males and females and the second CV distinguished major and minor males. This separation is obtained essentially by a size contrast among head width (HW), prothorax width (PW), elytra width (EW), and length of antennal segment VII. CVA was not undertaken for $H$. prasinata because it is only recommended when there are more than two groups (HAMMER 2002).

Allometry and sexual dimorphism. Results of analysis by the RMA in S. platyrhinus males, without separating major and minor groups (Table IV), showed positive allometry between the independent variable PL (prothorax length) and each of the six variables connected with the rostrum (rostral length 1 , apical width of rostrum, medial width 1 and 2 of rostrum, basal width of rostrum, and inter-scrobal distance). Even within the analysis of males, only one variable of the head, inter-eye width (IEW), and three antennal segments (the proximal III$\mathrm{V})$, did not fit an allometric pattern, differing from females of S. platyrhinus in this respect (Table IV).

Differing from the results above, evidence of sexual dimorphism with allometric patterns was confirmed only for females of $H$. prasinata in the following characters: width of head, prothorax, and elytra. Males of $H$. prasinata (Table IV) showed positive allometry for only one trait in the antennae (segment III). Males and females of this species, however, showed positive allometry in thirteen measurements, whereas females showed exclusive positive allometry in five traits. 


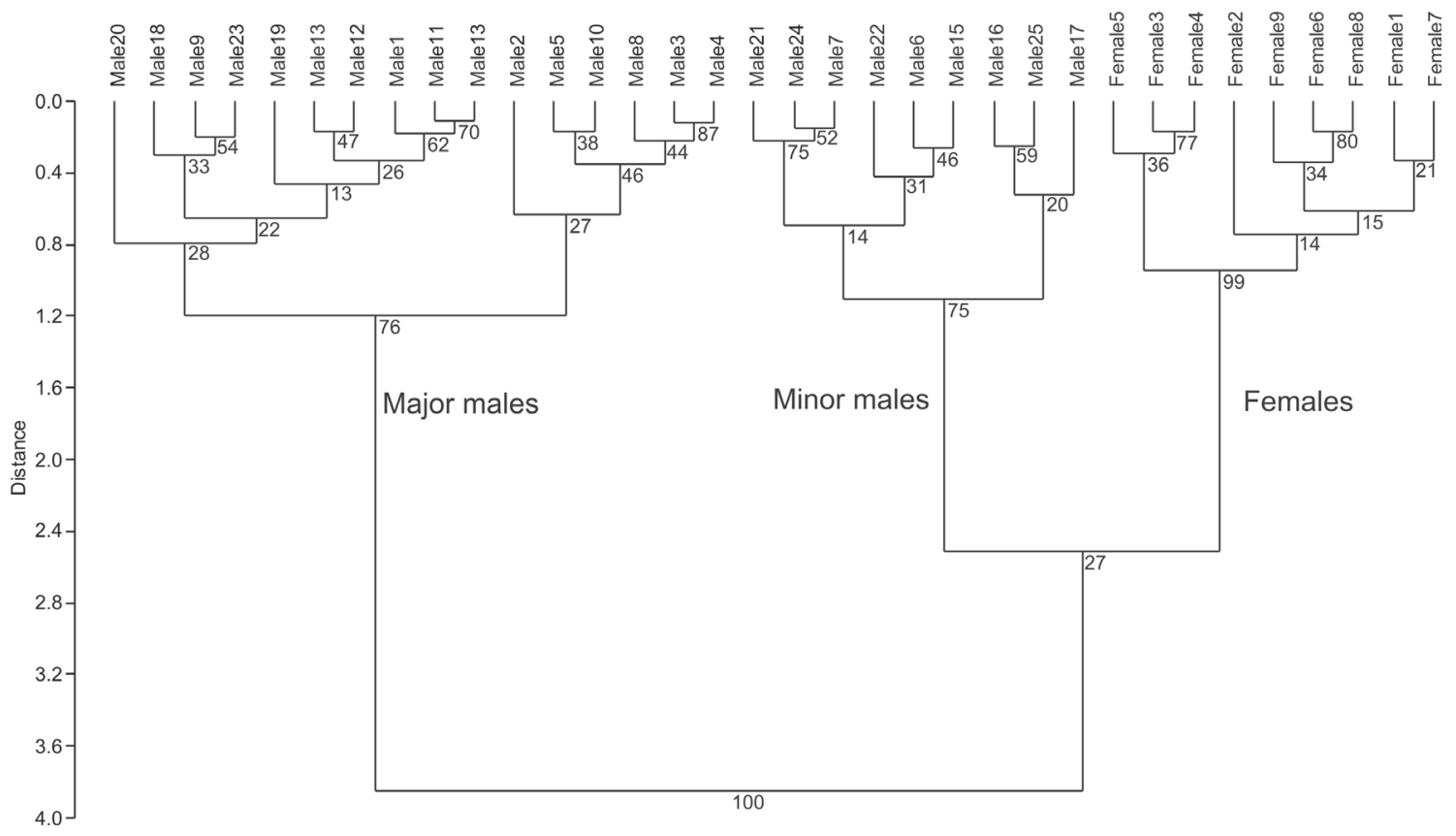

Figure 13. Dendogram obtained with Ward's Cluster Analysis methods for S. platyrhinus. 1,000 bootstrap replicates.

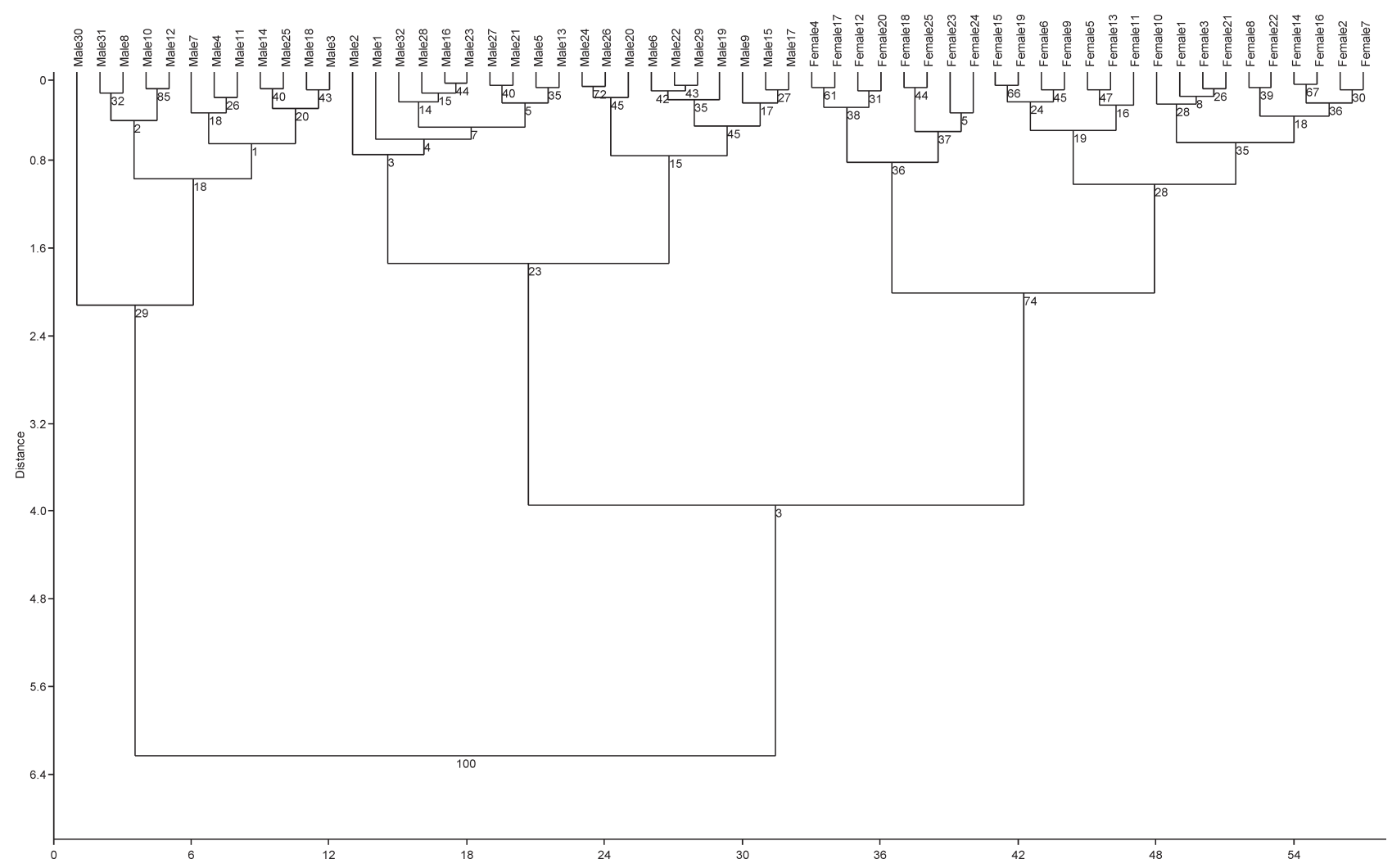

Figure 14. Dendogram obtained with Ward's Cluster Analysis methods for H. prasinata. 1,000 bootstrap replicates. 
Allometry and polyphenism in males. In reviewing the evidence of allometry between major and minor males of $S$. platyrhynus (Table III), five variables from the rostrum (RAW, MW1R, MW2R, RBW, and DIS), two of antennomeres (III) and only one from the ventrite (VL IV) have positive allometry only in major males. On the other hand, minor males showed positive allometry in prothorax and elytral width, and length of rostrum and antennomeres II, III, and VI. This demonstrates a clear morphological plasticity between males.

\section{DISCUSSION}

According to Kawano (2006), body size is the most appropriate morphological trait for allometric analyses because it depends on the quality of the nutrition received by an individual during growth. However, other traits have been used as allometric predictors, for instance elytra length (CLARK 1977, GoldsMith 1985), elytra width (EвERHARD 1980, СоOK 1987), and pronotum width (EMLem 1994, 1996, EBerhard et al. 1998, EMLEN et al. 2005, TOMKINS et al. 2005). KAWANO (2006) stated that in sexually dimorphic beetles characters such as elytra length (EL), elytra width (EW), and prothorax width (PW) are not adequate allometric predictors because they do not represent a true measurement of body size (see Moczer et al. 2002 for a different view). Notably, we know that nutritional and environmental factors influence body size and also dimorphic structures, and that body size, as a dimorphic structure, is determined by endocrine mechanisms regulating development (EMLEN et al. 2005).

We did not use the TL as an allometric predictor because it is a composite measure formed by the sum of rostral length (RL1), prothorax length (PL), and elytra length (EL). Moreover, all these traits exhibited positive allometry (see discussion below), which could lead, through high correlations, to an indirect correlation. In addition, the elytra width (EW) showed positive allometry for males of $S$. platyrhinus and $H$. prasinata, and females of $H$. prasinata. Thus, only the prothorax length (PL) was used as a proxy for the true size of the body in the subsequent allometric analysis.

The results on variation in monomorphic characters also corroborated the work of Holloway (1982), who postulated that the inter-scrobal distance (DIS) is a diagnostic character for genera in Anthribidae. Our results also showed that the DIS did not differ between sexes because it is a monomorphic character. Additionally, the results showed that, in a supposedly dimorphic structure such as the rostrum, there are measurements that do not vary between the sexes (monomorphic). For $H$. prasinata there were no differences between the sexes in rostral length (RL1). For S. platyrhynus, there were no differences in: (1) rostrum, the average width 1 (MW1B) and width 2 (MW2R); (2) antenna, length of antennomere II; and (3) abdomen, length of ventrite IV (VL IV).

Sexual dimorphism was discussed by Holloway (1982) and Mermudes \& NAPP (2006); it occurs in the relative length of the
Table III. The results based on regression. Reduced Major Axis regression (RMA) of pairs of morphological variables selected with positive allometry in S. platyrhinus. Prothorax length ( $\mathrm{PL}$ ) was used as a predictor variable, and all variables were log-transformed prior to the two male groups (major and minor). Values of positive allometry shown in bold, with slope $>1$ and $p \leqslant 0.05$.

\begin{tabular}{|c|c|c|c|c|c|}
\hline Measures & Males & Slope & $\mathrm{r}$ & $\mathrm{p}$ & $95 \%$ IC \\
\hline \multirow[t]{2}{*}{$\overline{R L 1}$} & Major Males & -1.48550 & -0.093925 & 0.7255 & $-2.2580 ; 1.7650$ \\
\hline & Minor Males & 1.81560 & 0.758530 & 0.0181 & $1.0100 ; 2.8050$ \\
\hline \multirow[t]{2}{*}{ RAW } & Major Males & 1.22850 & 0.656570 & 0.0053 & $0.7506 ; 1.7230$ \\
\hline & Minor Males & 0.96200 & 0.899870 & 0.0020 & $0.6779 ; 1.2760$ \\
\hline \multirow[t]{2}{*}{ MW1R } & Major Males & 1.22850 & 0.656570 & 0.0053 & $0.7506 ; 1.7230$ \\
\hline & Minor Males & 1.55180 & 0.218300 & 0.5583 & $-2.2640 ; 2.5990$ \\
\hline \multirow[t]{2}{*}{ MW2R } & Major Males & 1.75670 & 0.762370 & 0.0005 & $1.0840 ; 2.4550$ \\
\hline & Minor Males & 1.33680 & 0.802830 & 0.0143 & $0.8597 ; 1.9060$ \\
\hline \multirow[t]{2}{*}{ RBW } & Major Males & 1.39400 & 0.652370 & 0.0054 & $0.6713 ; 1.9830$ \\
\hline & Minor Males & 1.39230 & 0.815180 & 0.0089 & $0.8295 ; 1.9170$ \\
\hline \multirow[t]{2}{*}{$\mathrm{HW}$} & Major Males & 0.96648 & 0.565020 & 0.0229 & $0.6182 ; 1.3610$ \\
\hline & Minor Males & 0.85738 & 0.742430 & 0.0168 & $0.4798 ; 1.2800$ \\
\hline \multirow[t]{2}{*}{ PW } & Major Males & 0.93269 & 0.678800 & 0.0030 & $0.5844 ; 1.2920$ \\
\hline & Minor Males & 1.08050 & 0.842200 & 0.0026 & $0.6262 ; 1.5120$ \\
\hline \multirow[t]{2}{*}{ L } & Major Males & 0.80780 & 0.619160 & 0.0099 & $0.5425 ; 1.0200$ \\
\hline & Minor Males & 0.77868 & 0.619390 & 0.0818 & $-0.6077 ; 1.1640$ \\
\hline \multirow[t]{2}{*}{ EW } & Major Males & 0.99183 & 0.657430 & 0.0059 & $0.6287 ; 1.3850$ \\
\hline & Minor Males & 1.09810 & 0.819920 & 0.0034 & $0.6483 ; 1.7040$ \\
\hline \multirow[t]{2}{*}{ MEW } & Major Males & 1.14760 & 0.363730 & 0.1763 & $-1.3830 ; 1.6280$ \\
\hline & Minor Males & 0.75328 & 0.862790 & 0.0029 & $0.5855 ; 0.9414$ \\
\hline \multirow[t]{2}{*}{ DIS } & Major Males & 3.04740 & 0.530800 & 0.0355 & $1.4770 ; 4.4360$ \\
\hline & Minor Males & 1.66940 & 0.474440 & 0.1888 & $-1.7580 ; 2.6060$ \\
\hline \multirow[t]{2}{*}{ IEW } & Major Males & 1.23250 & 0.534230 & 0.0283 & $0.5754 ; 1.9310$ \\
\hline & Minor Males & 1.15860 & 0.813750 & 0.0102 & $0.7183 ; 1.5460$ \\
\hline \multirow[t]{2}{*}{ II } & Major Males & 2.61660 & 0.277900 & 0.3112 & $-1.9190 ; 4.4160$ \\
\hline & Minor Males & 1.40660 & 0.894920 & 0.0016 & $0.8673 ; 1.8060$ \\
\hline \multirow[t]{2}{*}{ III } & Major Males & 2.63410 & 0.577120 & 0.0139 & $1.1790 ; 4.4660$ \\
\hline & Minor Males & 1.23150 & 0.930700 & 0.0007 & $0.9571 ; 1.5440$ \\
\hline \multirow[t]{2}{*}{ IV } & Major Males & 1.70980 & 0.494290 & 0.0512 & $0.9584 ; 2.6600$ \\
\hline & Minor Males & 1.90930 & 0.661310 & 0.0546 & $1.1760 ; 2.8730$ \\
\hline \multirow[t]{2}{*}{ V } & Major Males & 1.13960 & 0.434660 & 0.0868 & $-0.5834 ; 1.8540$ \\
\hline & Minor Males & 1.75840 & 0.644540 & 0.0652 & $0.9586 ; 2.5610$ \\
\hline \multirow[t]{2}{*}{$\mathrm{VI}$} & Major Males & 0.74156 & 0.419830 & 0.1016 & $-0.6722 ; 1.0240$ \\
\hline & Minor Males & 1.88570 & 0.672400 & 0.0489 & $1.0130 ; 2.8120$ \\
\hline \multirow[t]{2}{*}{ VII } & Major Males & 0.73473 & 0.286160 & 0.2817 & $-0.9168 ; 0.9983$ \\
\hline & Minor Males & 1.59160 & 0.596570 & 0.0893 & $-1.0050 ; 2.3940$ \\
\hline \multirow[t]{2}{*}{ VIII } & Major Males & 1.15560 & 0.397810 & 0.1253 & $-1.4790 ; 1.6420$ \\
\hline & Minor Males & 1.37890 & 0.456590 & 0.2185 & $-1.0770 ; 2.2130$ \\
\hline \multirow[t]{2}{*}{ IX } & Major Males & 1.60190 & 0.347030 & 0.1804 & $-1.9980 ; 2.3000$ \\
\hline & Minor Males & 1.19260 & 0.657950 & 0.0557 & $0.6023 ; 1.7510$ \\
\hline \multirow[t]{2}{*}{$\mathrm{x}$} & Major Males & 1.77750 & 0.281690 & 0.3055 & $-2.8070 ; 2.7750$ \\
\hline & Minor Males & 0.94794 & 0.432220 & 0.2407 & $-0.8429 ; 1.3880$ \\
\hline \multirow[t]{2}{*}{$\mathrm{XI}$} & Major Males & 1.37250 & 0.502660 & 0.0498 & $0.8856 ; 2.0770$ \\
\hline & Minor Males & 1.13450 & 0.572490 & 0.1132 & $-0.3999 ; 1.7300$ \\
\hline VL IV & Major Males & 1.64070 & 0.701600 & 0.0017 & $0.9728 ; 2.4760$ \\
\hline & Minor Males & 0.91300 & 0.015324 & 0.9692 & $-1.2600 ; 1.4550$ \\
\hline VL V & Major Males & 1.80020 & 0.219740 & 0.4421 & $-1.2380 ; 3.1420$ \\
\hline & Minor Males & 1.34300 & 0.466900 & 0.2049 & $-0.8419 ; 2.1480$ \\
\hline
\end{tabular}


Table IV. Reduced Major Axis regression (RMA) results between pairs of morphological variables selected with positive allometry in S. platyrhinus and $H$. prasinata. Prothorax length $(\mathrm{PL})$ was used as a predictor variable. All variables were log-transformed prior to males and females. $\left.{ }^{(* \star}\right)$ for $p \leqslant 0.0001$.

\begin{tabular}{|c|c|c|c|c|c|c|c|c|c|}
\hline \multirow{2}{*}{ Measures } & \multicolumn{5}{|c|}{ S. platyrhinus } & \multicolumn{4}{|c|}{ H. prasinata } \\
\hline & Sex & Slope b & $\mathrm{r}$ & $\mathrm{p}$ & I.C. & Slope b & $\mathrm{r}$ & $\mathrm{p}$ & I.C. \\
\hline \multirow[t]{2}{*}{ RL1 } & Males & 1.90000 & 0.699050 & 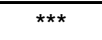 & $1.4610 ; 2.3560$ & 1.06040 & 0.931790 & $\star \star \star *$ & $0.9302 ; 1.1910$ \\
\hline & Females & 0.59137 & 0.440290 & 0.2449 & $-0.4048 ; 1.800$ & 1.10600 & 0.940410 & $* * *$ & $0.9485 ; 1.3050$ \\
\hline \multirow[t]{2}{*}{ RAW } & Males & 1.16070 & 0.875300 & $* * *$ & $1.0080 ; 1.3720$ & -4.99440 & -0.058107 & 0.7606 & $-9.096 ; 4.3820$ \\
\hline & Females & -0.41585 & -0.078700 & 0.8496 & $-0.7777 ; 1.1800$ & 0.98130 & 0.919110 & $* * *$ & $0.8439 ; 1.2070$ \\
\hline \multirow[t]{2}{*}{ MW1R } & Males & 1.68740 & 0.549920 & 0.0064 & $1.0480 ; 2.5660$ & - & - & - & - \\
\hline & Females & -0.32354 & -0.012680 & 0.9765 & $-0.4807 ; 0.9039$ & - & - & - & - \\
\hline \multirow[t]{2}{*}{ MW2R } & Males & 1.60640 & 0.878990 & 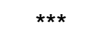 & $1.3820 ; 1.9150$ & - & - & - & - \\
\hline & Females & 0.41981 & 0.038053 & 0.9181 & $-0.5954 ; 1.2100$ & - & - & - & - \\
\hline \multirow[t]{2}{*}{ RBW } & Males & 1.50130 & 0.863070 & $\star \star \star *$ & $1.2590 ; 1.7940$ & 1.17200 & 0.873160 & $\star \star \star *$ & $0.8929 ; 1.4110$ \\
\hline & Females & 0.53790 & 0.031836 & 0.9298 & $-1.0410 ; 1.6160$ & 1.02050 & 0.972850 & $\star \star \star *$ & $0.9115 ; 1.1610$ \\
\hline \multirow[t]{2}{*}{ HW } & Males & 1.03900 & 0.823670 & $* * *$ & $0.8540 ; 1.2510$ & 0.91548 & 0.953520 & *** & $0.8060 ; 1.0180$ \\
\hline & Females & 0.47593 & 0.043096 & 0.9097 & $-0.9619 ; 1.4070$ & 1.02800 & 0.975950 & $\star \star * *$ & $0.9448 ; 1.1690$ \\
\hline \multirow[t]{2}{*}{ PW } & Males & 1.04600 & 0.875940 & $\star \star * *$ & $0.8642 ; 1.2310$ & 0.99005 & 0.961220 & *** & $0.8782 ; 1.0860$ \\
\hline & Females & 0.41758 & 0.088446 & 0.8306 & $-0.7940 ; 1.1870$ & 1.10450 & 0.985070 & $\star \star * *$ & $1.0230 ; 1.2320$ \\
\hline \multirow[t]{2}{*}{ EL } & Males & 0.90022 & 0.807660 & $* * *$ & $0.7675 ; 1.0580$ & 0.98289 & 0.967430 & *** & $0.8957 ; 1.0540$ \\
\hline & Females & 0.43514 & 0.348030 & 0.3544 & $-0.1564 ; 1.1820$ & 1.05030 & 0.988480 & *** & $0.9686 ; 1.1080$ \\
\hline \multirow[t]{2}{*}{ EW } & Males & 1.05590 & 0.860950 & $\star * *$ & $0.8797 ; 1.2260$ & 0.98049 & 0.974080 & $* * *$ & $0.8989 ; 1.0570$ \\
\hline & Females & 0.45187 & 0.155270 & 0.6926 & $-0.6374 ; 1.370$ & 1.08220 & 0.983880 & $* * *$ & $1.0170 ; 1.1800$ \\
\hline \multirow[t]{2}{*}{ MEW } & Males & 0.82335 & 0.695740 & $* * *$ & $0.6704 ; 1.0870$ & 0.78105 & 0.814940 & $\star * *$ & $0.6461 ; 0.9124$ \\
\hline & Females & -0.34873 & -0.10388 & 0.8103 & $-0.4492 ; 0.9072$ & 0.87605 & 0.936000 & $\star \star \star *$ & $0.7657 ; 1.0860$ \\
\hline \multirow[t]{2}{*}{ DIS } & Males & 2.07910 & 0.649830 & 0.0008 & $1.5690 ; 2.8290$ & 1.12190 & 0.872020 & *** & $0.8799 ; 1.3570$ \\
\hline & Females & 0.45967 & 0.465290 & 0.2183 & $0.1739 ; 1.2460$ & 1.04790 & 0.970210 & $\star \star * *$ & $0.9672 ; 1.2050$ \\
\hline \multirow[t]{2}{*}{ IEW } & Males & 1.35670 & 0.835360 & $\star \star *$ & $1.1270 ; 1.6580$ & 1.15460 & 0.889160 & $\star \star \star *$ & $0.9594 ; 1.3300$ \\
\hline & Females & 0.59589 & 0.116280 & 0.723 & $-0.8943 ; 1.8360$ & 1.04290 & 0.957510 & $\star \star * *$ & $0.9386 ; 1.1890$ \\
\hline \multirow[t]{2}{*}{ II } & Males & 1.71650 & 0.620900 & 0.0005 & $0.9697 ; 2.6140$ & 1.82900 & 0.917990 & *** & $1.5820 ; 2.0320$ \\
\hline & Females & -0.94552 & -0.729110 & 0.0761 & $-1.1480 ; 1.3230$ & 1.03330 & 0.908060 & $* * *$ & $0.9029 ; 1.3000$ \\
\hline \multirow[t]{2}{*}{ III } & Males & 1.69210 & 0.740040 & $* * *$ & $1.1920 ; 2.5400$ & 1.92700 & 0.959180 & *** & $1.7420 ; 2.1320$ \\
\hline & Females & -1.07410 & -0.089660 & 0.8043 & $-1.2830 ; 2.8000$ & 1.01900 & 0.933010 & *** & $0.9035 ; 1.2060$ \\
\hline \multirow[t]{2}{*}{ IV } & Males & 1.68500 & 0.749730 & $* * *$ & $1.2730 ; 2.1020$ & 2.24450 & 0.972940 & *** & $2.0800 ; 2.4190$ \\
\hline & Females & -0.44250 & 0.378060 & 0.3446 & $-1.2100 ; 0.8810$ & 1.07030 & 0.939310 & $\star \star * *$ & $0.9352 ; 1.2770$ \\
\hline \multirow[t]{2}{*}{ v } & Males & 1.54270 & 0.761590 & 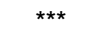 & $1.1060 ; 1.9080$ & 6.15970 & 0.526750 & $\star \star \star *$ & $2.5750 ; 10.8700$ \\
\hline & Females & 0.49559 & 0.074484 & 0.8421 & $-1.2560 ; 1.4010$ & 1.07280 & 0.916670 & *** & $0.9190 ; 1.2640$ \\
\hline $\mathrm{Vl}$ & Males & 1.51620 & 0.764820 & $* \star *$ & $0.9724 ; 1.9400$ & 2.99950 & 0.944720 & $\star \star * *$ & $2.8050 ; 3.2500$ \\
\hline & Females & -0.45601 & -0.077770 & 0.8245 & $-0.8710 ; 1.4290$ & 1.02590 & 0.879440 & $\star \star * *$ & $0.8348 ; 1.2660$ \\
\hline VII & Males & 1.34630 & 0.727210 & 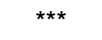 & $0.9090 ; 1.7510$ & 2.83610 & 0.916910 & $\star * *$ & $2.5600 ; 3.1810$ \\
\hline & Females & -0.44280 & -0.023300 & 0.9504 & $-0.8681 ; 1.3760$ & 0.95728 & 0.824990 & $\star \star \star *$ & $0.8010 ; 1.2830$ \\
\hline VIII & Males & 1.27890 & 0.686200 & 0.0002 & $0.8871 ; 1.6360$ & 2.56950 & 0.924410 & $* * *$ & $2.248 ; 2.9630$ \\
\hline & Females & 0.56072 & 0.210630 & 0.5876 & $-0.9753 ; 1.6330$ & 1.12210 & 0.613780 & 0.0013 & $0.8289 ; 1.7310$ \\
\hline IX & Males & 1.19600 & 0.641790 & 0.0005 & $0.8995 ; 1.5690$ & 2.70990 & 0.836270 & $* * *$ & $2.2630 ; 3.1940$ \\
\hline & Females & -0.97553 & -0.262960 & 0.406 & $-1.7080 ; 2.6140$ & 1.02260 & 0.415650 & 0.0415 & $-0.9485 ; 1.4340$ \\
\hline$x$ & Males & 1.07710 & 0.400380 & 0.0479 & $0.5625 ; 1.6440$ & 1.66220 & 0.743030 & $* * *$ & $1.3390 ; 2.0690$ \\
\hline & Females & -0.96886 & -0.548470 & 0.1422 & $-2.400 ; 1.5710$ & 1.28970 & 0.746940 & $* * *$ & $1.0500 ; 1.6130$ \\
\hline XI & Males & 1.06410 & 0.671810 & 0.0004 & $0.8033 ; 1.3920$ & 2.27550 & 0.836560 & $* * *$ & $1.8510 ; 2.7770$ \\
\hline & Females & -0.86524 & -0.41590 & 0.2525 & $-2.3730 ; 0.7534$ & 1.52600 & 0.665790 & 0.0001 & $1.1680 ; 2.0830$ \\
\hline VL IV & Males & 1.24970 & 0.665430 & $\star * \star$ & $0.9291 ; 1.7370$ & 0.79050 & 0.705380 & $* * *$ & $0.6296 ; 0.9581$ \\
\hline & Females & -0.62952 & -0.237740 & 0.546 & $-1.3870 ; 1.7320$ & 0.95457 & 0.932760 & $\star * *$ & $0.8309 ; 1.0880$ \\
\hline VL V & Males & 1.26970 & 0.484400 & 0.0123 & $0.6120 ; 1.9140$ & 0.88102 & 0.814830 & *** & $0.6817 ; 1.0890$ \\
\hline & Females & -1.07080 & -0.285230 & 0.3561 & $-2.9930 ; 1.1460$ & 0.85026 & 0.925360 & $\star * *$ & $0.7052 ; 0.9477$ \\
\hline
\end{tabular}


Table V. Loadings of the morphometric variables in the first two components of the Principal Components Analysis (PCA). Variables not measured marked with an asterisk.

\begin{tabular}{lccccc}
\hline \multirow{2}{*}{ Measures } & \multicolumn{2}{c}{ S. platyrhinus } & & \multicolumn{2}{c}{ H. prasinata } \\
\cline { 2 - 3 } \cline { 5 - 6 } RL1 & PC1 & PC2 & & PC1 & PC2 \\
\hline RAW & -0.544 & -0.114 & & 0.135 & -0.183 \\
MW1R & -0.150 & -0.240 & & 0.108 & -0.182 \\
MW2R & 0.015 & -0.318 & & $*$ & $*$ \\
RBW & -0.353 & -0.225 & & $*$ & $*$ \\
HW & -0.375 & -0.213 & & 0.095 & -0.214 \\
PL & -0.156 & -0.222 & & 0.079 & -0.200 \\
PW & -0.098 & -0.229 & & 0.124 & -0.178 \\
EL & -0.153 & -0.248 & & 0.100 & -0.206 \\
EW & -0.127 & -0.234 & & 0.110 & -0.191 \\
MEW & -0.156 & -0.259 & & 0.091 & -0.207 \\
DIS & -0.027 & -0.126 & & 0.073 & -0.148 \\
IEW & -0.295 & -0.224 & & 0.088 & -0.210 \\
II & -0.199 & -0.204 & & 0.115 & -0.199 \\
III & -0.076 & -0.052 & & 0.398 & -0.096 \\
IV & -0.401 & 0.066 & & 0.565 & -0.009 \\
V & -0.551 & 0.158 & & 0.613 & -0.027 \\
VI & -0.600 & 0.174 & & 1.018 & 0.087 \\
VII & -0.583 & 0.187 & & 0.845 & 0.048 \\
VIII & -0.561 & 0.211 & & 0.864 & 0.104 \\
IX & -0.459 & 0.157 & & 0.815 & 0.115 \\
X & -0.227 & 0.043 & & 0.583 & 0.010 \\
XI & -0.102 & 0.018 & & 0.308 & -0.109 \\
VL IV & -0.174 & 0.011 & & 0.554 & -0.045 \\
VL V & -0.030 & 0.117 & & -0.002 & -0.199 \\
\hline & 0.037 & -0.134 & & -0.056 & -0.235 \\
\hline & & & &
\end{tabular}

antenna of males of some Anthribinae. Also, Mermudes (2005) used a relationship between the length of ventrites IV and V to distinguish between males and females of Hypselotropis Jekel, 1855. Our results here show that ventrite $\mathrm{V}$ is always longer than ventrite IV in both males and females of $H$. prasinata. This differs from the opinion of Mermudes (2005) who believes that ventrite $\mathrm{V}$ in males is always slightly shorter than ventrite IV. However, our results confirmed this relationship for females. The large number of variables with values also tested by PCA and CVA (Figs 15-17) suggest that there is marked sexual dimorphism in some structural characters that had not been previously investigated.

The multivariate analysis (PCA) indicated that two relatively discrete groups of males of $S$. platyrhinus exist with respect to size (major males, minor males and females, Fig. 15), which was confirmed by CVA (Fig. 17), revealing the presence of polyphenism in males of this species. The analysis suggested that the allometric component contributes to the differentiation of groups, but there is no evidence of polyphenism in males of $H$. prasinata (Fig. 16), rejecting, at least in this analysis, the hypothesis of size polyphenism in this species.
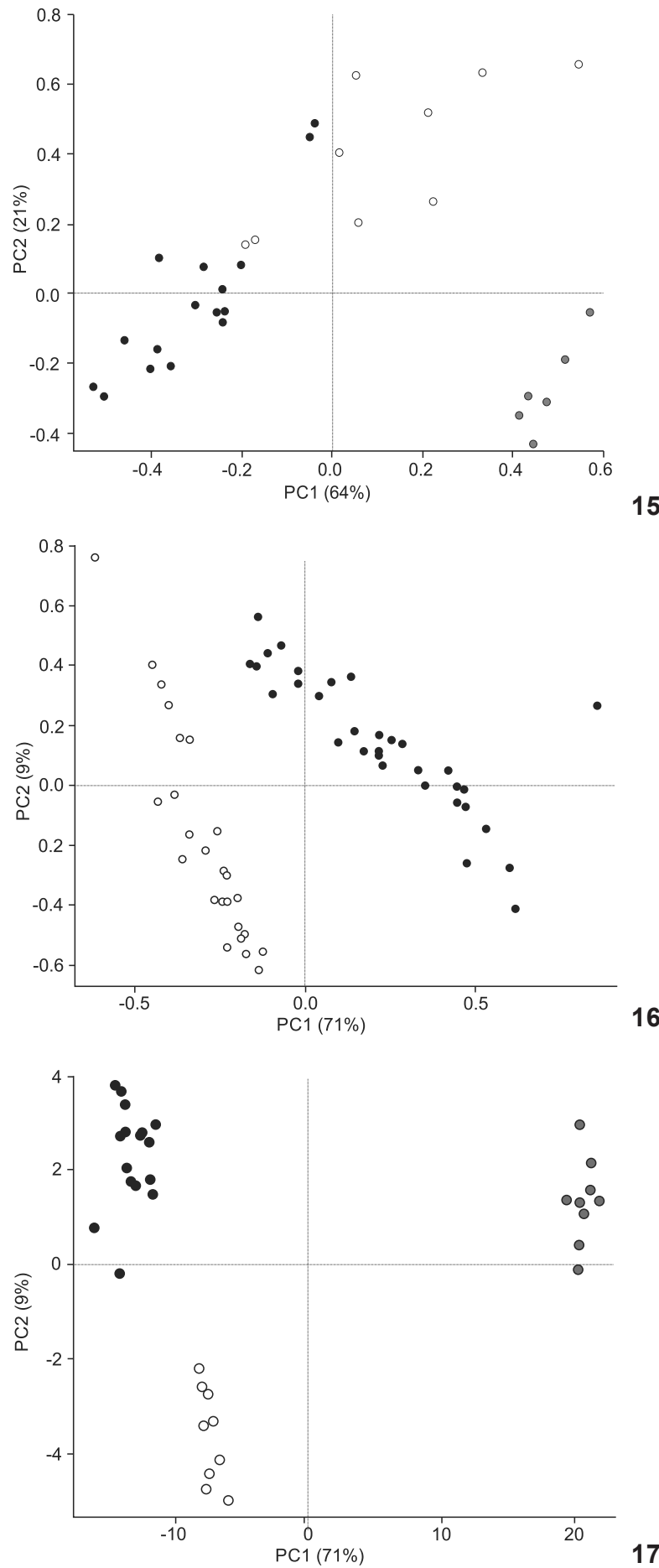

Figures 15-17. (15-16) Principal Components Analysis (PCA) for: (15) S. platyrhynus: females $(\bigcirc)$, major males $(\bullet)$, and minor males (light gray); (16) H. prasinata: females ( $\bigcirc$ ) and males (๑); (17) Canonical Variate Analysis (CVA) of S. platyrhinus: females (O), major males $(\bullet)$, and minor males $(\bigcirc)$. 
Considering together all the results on allometry and sexual dimorphism, we conclude that, in the case of $S$. platyrhinus, the dimensions of the rostrum, antennal segments, and ventrites IV and $\mathrm{V}$ indicate that sexual dimorphism is in place, as previously suggested by Mermudes (2002). Traits that exhibited positive allometry are a strong indication of sexual dimorphism (Emlen 1996, MoczeK et al. 2002, Matsuo 2005, Mосzек 2006). It is worth noting that the variables with positive allometry in S. platyrhinus are at the anterior part of body (rostrum and frons). In this species, the rostrum and forehead are vertical (hypognathous), providing evidence that such structures are subject to sexual selection and are probably associated with male fighting, similar to the condition found in Exechesops leucopis.

Despite the fact that we have analyzed only two species, our results emphasize allometric patterns in structures with sexual dimorphism that can be highly variable within $S$. platyrhynus males. Almost all species of Anthribidae that show sexual dimorphism lack structures known as weapons (e.g., horns). Polyphenism in males was also found to be present in S. platyrhinus, making it possible to infer that many traits related to dimorphism could play a role in tactical alternatives that minor males developed when confronted with major males, as reported by Howden (1992), YoshitaKe \& KaWASHIMA (2004), and Matsuo (2005).

Initially, the allometric variation could be derived from either behavioral differences between major or minor males or from a threshold size to developing weapons (horns or mandibles) with exaggerated sizes (MосZEK \& EMLEN 2000, MoczeK et al. 2002, Yoshitake \& KaWashima 2004, Matsuo 2005). In males of some species of Anthribidae (which do not have horns = weapons), sexually dimorphic traits exhibit positive allometry with body size, whereas isometry or negative allometry is detected when sexually monomorphic traits are considered (or which are not associated with dimorphism) (MATsuo 2005).

The behavioral relationship involves male-male competition for females, but it does not eliminate the interactions between minor males when they meet, as well as alternative tactics developed by minor males to copulate (EMLEN 1994, Moczeк et al. 2002, Matsuo 2005, Tomkins \& Moczeк 2009).

Finally, it is possible that the morphological patterns of Anthribidae are linked to the protection of the female, which is secured by males during oviposition, and that a relationship between reproductive behavior and alternative morphologies exists (as noted by Howden 1992). This behavioral pattern can be elucidated in further studies on S. platyrhinus.

\section{ACKNOWLEDGMENTS}

We are grateful to the curators who made material available and to two anonymous reviewers for comments. This research was partially supported by grants from CNPq (processes 470980/2011-7, 475461/2007, and 312357/2006), FAPERJ (pro- cesses 101.476/2010 and 100.927/2011), and Programa de PósGraduação em Biociências da Universidade do Estado do Rio de Janeiro.

\section{LITERATURE CITED}

CLARK, J.T. 1977. Aspects of variation in the stag beetle Lucanus cervus (L.) (Coleoptera: Lucanidae). Systematic Entomology 2: 9-16. doi: 10.1111/j.1365-3113.1977.tb00350.x.

Соок, D. 1987. Sexual selection in dung beetles. I. A multivariate study of the morphological variation in two species of Onthophagus (Scarabaeidae: Onthophagini). Australian Journal of Zoology 35: 123-132. doi: 10.1071/ZO9870123.

Eberhard, W.G. 1980. Horned beetles. Scientific American 242: 166-182.

Eвerhard, W.G. \& E.E. Gutiérez. 1991. Morphometric Variability in Continental and Atlantic Island Populations of Chaffinches Fringilla coelebs. Evolution 45 (1): 29-39.

Eberhard, W.G.; B.A. Huber; R.L. Rodriguez; R.D. Briceno; I. Salas \& V. Rodriguez. 1998. One size fits all? Relationships between the size and degree of variation in genitalia and other body parts in twenty species of insects and spiders. Evolution 52: 415-431.

EmLEN, D.J. 1994. Environmental control of horn length dimorphism in the beetle Onthophagus acuminatus (Coleoptera: Scarabaeidae). Proceedings of the Royal Society B. 256: 131136. doi: 10.1098/rspb.1994.0060.

EmLen, D.J. 1996. Artificial selection on horn length-body size allometry in the horned beetle Onthophagus acuminatus (Coleoptera:Scarabaeidae). Evolution 50: 1219-1230.

EmLen, D.J. 2008. The evolution of animal weapons. Annual Review of Ecology and Systematics 39: 387-413. doi: 10.1146/annurev.ecolsys.39.110707.173502.

Emlen, D.J. \& H.F. Nijhout. 2000. The Development and Evolution of Exaggerated Morphologies in Insects. Annual Review of Entomology 45: 661-708. doi: 10.1146/ annurev.ento.45.1.661.

Emlen, D.J.; J. Hunt \& L.W. Simmons. 2005. Evolution of sexual dimorphism and male dimorphism in the expression of beetle horns: phylogenetic evidence for modularity, evolutionary lability, and constraint. The American Naturalist 166 (Suppl.): S42-S68.

Emlen, D.J.; L.C. Lavine \& B. Ewen-Campen. 2007. On the origin and evolutionary diversification of beetle horns. Proceedings of the National Academy of Sciences 104: 8661-8668.

Goldsmith, S.K. 1985. Male Dimorphism in Dendrobias mandibularis Audinet-Serville (Coleoptera: Cerambycidae). Journal of the Kansas Entomological Society 58: 534-538. Gould, S.J. 1966. Allometry and size in ontogeny and phylogeny. Biological Reviews 41: 587-640. doi: 10.1111/ j.1469-185X.1966.tb01624.x

Hammer, O. 2002. Morphometrics - brief notes50p. Available at http://folk.uio.no/ohammer/past/morphometry.pdf [Accessed: February 2014]. 
Hammer, O.; D.A.T. Harper \& P.D. Ryan. 2001. Past: Palaeontological Statistics Software Package for Education and Data Analysis. Palaeontological Electronica 4 (1): 9p. Available online at: http://palaeo-electronica.org/2001_1/past/past.pdf [Accessed: March 2011].

Holloway, B.A. 1982. Anthribidae (Insecta: Coleoptera). Fauna of New Zealand 3. Wellington, DSIR, 269p.

Howden, A.T. 1992. Oviposition Behavior and Associated Morphology of the Neotropical Anthribid Ptychoderes rugicollis Jordan (Coleoptera: Anthribidae). Coleopterists Bulletin 46: 20-27.

Howden, A.T. 1995. Structures related to oviposition in Curculionoidea. Memoirs of the Entomological Society of Washington 14: 53-100.

HuXLEY, J.S. 1932. Problems of relative growth. London, Methuen, 276p.

Huxley, J.S. 1950. Relative growth and form transformation. Proceedings of the Royal Society London 137: 465-469. doi:10.1098/rspb.1950.0055.

KaWANO, K. 2000. Genera and Allometry in the Stag Beetle Family Lucanidae, Coleoptera. Annals of the Entomological Society of America 93: 198-207. doi: http://dx.doi.org/10.1603/00138746(2000)093[0198:GAAITS]2.0.CO;2.

Kawano, K. 2006. Sexual Dimorphism and the Making of Oversized Male Characters in Beetles (Coleoptera). Annals of the Entomological Society of America 99: 327-341. doi: doi: http://dx.doi.org/10.1603/0013-8746(2006)099[0327: SDATMO]2.0.CO;2.

Matsuo, Y. 2005. Extreme Eye Projection in the Male Weevil Exechesops leucopis (Coleoptera: Anthribidae): Its Effects on Intrasexual Behavioral Interferences. Journal of Insect Behavior 18: 465-477. doi: 10.1007/s10905-005-5605-y.

Mermudes, J.R.M. 2002. Systaltocerus platyrhinus Labram \& Imhoff, 1840: redescrições e considerações sobre a sinonímia com Homalorhamphus vestitus Haedo Rossi \& Viana, 1957 (Coleoptera, Anthribidae, Anthribinae). Revista Brasileira de Entomologia 46: 579-590. doi: http://dx.doi.org/ 10.1590/S0085-56262002000400013.

Mermudes, J.R.M. 2005. Revisão sistemática, análise cladística e biogeografia dos gêneros Tribotropis e Hypselotropis (Coleoptera, Anthribidae, Anthribinae, Ptychoderini). Revista Brasileira de Entomologia 49: 465-511. doi: http://dx.doi.org/ 10.1590/S0085-56262005000400009.

MeRMUDES, J.R.M. \& D.S. Napp. 2006. Revision and cladistic analysis of the genus Ptychoderes Schoenherr, 1823 (Coleoptera, Anthribidae, Anthribinae, Ptychoderini) Zootaxa 1182: 1-130.

Mermudes, J.R.M. \& I. Mattos. 2010. Description of Males of Ptychoderes brevis and Ptychoderes jekeli, with a cladistical reanalysis of Ptychoderes (Coleoptera: Anthribidae). Annals of the Entomological Society of America 105: 523-531. doi: http://dx.doi.org/10.1603/AN10016.

Mermudes, J.R.M. \& J.M.S. Rodrigues. 2010. Description of two new species of Hypselotropis Jekel with a revised key and phylogenetic reanalysis of the genus (Coleoptera, Anthribidae, Anthribinae). Zootaxa 2575: 49-62.

Moczek, A.P. 2006. A matter of measurements: challenges and approaches in the comparative analysis of static allometries. American Naturalist 167: 606-611.

Moczer, A.P. \& D.J. EmLen. 2000. Male horn dimorphism in the scarab beetle, Onthophagus taurus: do alternative reproductive tactics favour alternative phenotypes? Animal Behaviour 59: 459-466. doi: 10.1006/anbe.1999.1342.

Moczer, A.P.; J. Hunt; D.J. Emlen \& L.W. Simmons. 2002. Threshold evolution in exotic populations of a polyphenic beetle. Evolutionary Ecology Research 4: 587-601.

Oksanen, J.; F.G. Blanchet; R.P. Legendre; P.R. Minchin; R.B. O'Hara; G.L. Simpson; P. Solymos; M.H.H. Stevens \& H. Wagner. 2013. Vegan: Community Ecology Package. R package version 2.0-7. Available online at: http://cran.r-project.org/ web/packages/vegan/index.html [Accessed: July 2013]

Posadas, P.; E. Ortiz-Jaureguizar \& M.E. Pérez. 2007. Dimorfismo sexual y variación morfométrica geográfica en Hybreoleptops aureosignatus (Insecta: Coleoptera: Curculionidae). Anales de la Academia Nacional de Ciencias Exactas, Físicas y Naturales 59: 141-150.

R Core Team. 2013. R: A language and environment for statistical computing. Vienna, R Foundation for Statistical Computing. Available online at: http://www.R-project.org/ [Accessed: July 2013]

SCHLAger, S. 2013. Morpho: Calculations and visualizations related to Geometric Morphometrics. R package version 0.25. Available at http://sourceforge.net/projects/morphorpackage [Accessed: July 2013]

SHIOKAWA, T. \& O. IWAHASHI. 2000. Mandible dimorphism in males of a stag beetle, Prosopocoilus dissimilis okinawanus (Coleoptera: Lucanidae). Applied Entomology and Zoology 35 (4): 487-494. doi: 10.1303/aez.2000.487.

Slipinski, S.A.; R.A.B. Leschen \& J.F. Lawrence. 2011. Order Coleoptera Linnaeus, 1758. In: Z.Q. ZHANG (Ed.). Animal biodiversity: An outline of higher-level classification and survey of taxonomic richness. Zootaxa 3148: 203-208.

Tномpson, G.H. 1963. Forest Coleoptera of Ghana. Biological notes and host trees. Oxford, Forestry Memoirs 24, 78p.

Tomkins, J.L.; J.S. Котіано \& N.R. LeBas. 2005. Matters of scale: Positive allometry and the evolution of male dimorphisms. American Naturalist 165: 389-402.

Tomkins J.L. \& A.P. Moczeк. 2009. Patterns of threshold evolution in polyphenic insects under different developmental models. Evolution 62: 459-468. doi: 10.1111/j.1558-5646.2008. 00563.x.

VALENTIN, J.L. 2000. Ecologia numérica: Uma introdução à análise multivariada de dados ecológicos. Rio de Janeiro, Interciência, $117 \mathrm{p}$.

Yoshitake, H. \& I. KaWashima. 2004. Sexual Dimorphism and Agonistic Behavior of Exechesops leucopis (Jordan) (Coleoptera: Anthribidae: Anthribinae). The Coleopterists Bulletin 58: 77-83. 
Appendix 1. Mean, standard deviations, and variance measures of morphological characters of males and females of $S$. platyrhinus and H. prasinata. The result of the independent T test for sexual dimorphism is also shown. $\left.{ }^{* * *}\right)$ for $p \leqslant 0.0001$.

\begin{tabular}{|c|c|c|c|c|c|c|c|c|c|c|c|c|c|c|}
\hline \multirow{3}{*}{ Measures } & \multicolumn{7}{|c|}{ S. platyrhinus } & \multicolumn{7}{|c|}{ H. prasinata } \\
\hline & \multicolumn{3}{|c|}{ Males } & \multicolumn{3}{|c|}{ Females } & \multirow{2}{*}{$T$ test } & \multicolumn{3}{|c|}{ Males } & \multicolumn{3}{|c|}{ Females } & \multirow{2}{*}{$\mathrm{T}$ test } \\
\hline & Mean & SD & Variance & Mean & SD & Variance & & Mean & SD & Variance & Mean & SD & Variance & \\
\hline RL1 & 0.54 & 0.13 & 0.02 & 0.41 & 0.06 & 0.00 & 0.0091 & 0.45 & 0.01 & 0.07 & 0.44 & 0.01 & 0.09 & 0.4807 \\
\hline RAW & 0.21 & 0.08 & 0.01 & 0.23 & 0.04 & 0.00 & 0.3405 & 0.26 & 0.12 & 0.34 & 0.21 & 0.01 & 0.08 & 0.6784 \\
\hline MW1R & 0.03 & 0.12 & 0.01 & 0.16 & 0.03 & 0.00 & 0.0041 & - & - & - & - & - & - & - \\
\hline MW2R & 0.30 & 0.11 & 0.01 & 0.23 & 0.04 & 0.00 & 0.1091 & - & - & - & - & - & - & - \\
\hline RBW & 0.38 & 0.10 & 0.01 & 0.31 & 0.05 & 0.00 & 0.0688 & 0.09 & 0.01 & 0.08 & 0.12 & 0.01 & 0.08 & 0.2619 \\
\hline HW & 0.30 & 0.07 & 0.01 & 0.32 & 0.05 & 0.00 & 0.4375 & 0.26 & 0.00 & 0.06 & 0.29 & 0.01 & 0.08 & 0.1792 \\
\hline $\mathrm{PL}$ & 0.31 & 0.07 & 0.00 & 0.34 & 0.10 & 0.01 & 0.2870 & 0.55 & 0.00 & 0.07 & 0.55 & 0.01 & 0.08 & 0.7185 \\
\hline PW & 0.37 & 0.07 & 0.01 & 0.40 & 0.04 & 0.00 & 0.3047 & 0.49 & 0.00 & 0.07 & 0.51 & 0.01 & 0.09 & 0.4486 \\
\hline $\mathrm{EL}$ & 0.65 & 0.06 & 0.00 & 0.68 & 0.04 & 0.00 & 0.3094 & 0.91 & 0.00 & 0.07 & 0.91 & 0.01 & 0.08 & 0.8098 \\
\hline EW & 0.42 & 0.07 & 0.01 & 0.45 & 0.05 & 0.00 & 0.2969 & 0.58 & 0.00 & 0.07 & 0.60 & 0.01 & 0.09 & 0.3034 \\
\hline MEW & -0.03 & 0.06 & 0.00 & 0.02 & 0.04 & 0.00 & 0.0231 & 0.08 & 0.00 & 0.05 & 0.09 & 0.00 & 0.07 & 0.6900 \\
\hline DIS & 0.11 & 0.14 & 0.02 & 0.05 & 0.05 & 0.00 & 0.2983 & 0.09 & 0.01 & 0.08 & 0.11 & 0.01 & 0.08 & 0.2525 \\
\hline IEW & 0.09 & 0.09 & 0.01 & 0.09 & 0.06 & 0.00 & 0.8413 & 0.07 & 0.01 & 0.08 & 0.07 & 0.01 & 0.08 & 0.8187 \\
\hline II & -0.56 & 0.12 & 0.01 & -0.60 & 0.10 & 0.01 & 0.4182 & -0.18 & 0.02 & 0.13 & -0.36 & 0.01 & 0.08 & $\star * *$ \\
\hline III & -0.05 & 0.12 & 0.01 & -0.35 & 0.11 & 0.01 & $\star * \star$ & 0.13 & 0.02 & 0.13 & -0.19 & 0.01 & 0.08 & $* * *$ \\
\hline IV & 0.02 & 0.12 & 0.01 & -0.41 & 0.04 & 0.00 & $* * *$ & 0.08 & 0.02 & 0.15 & -0.25 & 0.01 & 0.09 & $\star \star \star$ \\
\hline $\mathrm{V}$ & 0.06 & 0.11 & 0.01 & -0.40 & 0.05 & 0.00 & $* \star *$ & 0.14 & 0.18 & 0.43 & -0.33 & 0.01 & 0.09 & $\star \star \star$ \\
\hline VI & 0.04 & 0.10 & 0.01 & -0.42 & 0.05 & 0.00 & $* * *$ & 0.09 & 0.04 & 0.21 & -0.39 & 0.01 & 0.08 & $\star * *$ \\
\hline VII & 0.01 & 0.09 & 0.01 & -0.49 & 0.04 & 0.00 & $\star \star *$ & 0.09 & 0.04 & 0.20 & -0.42 & 0.01 & 0.08 & $\star \star \star$ \\
\hline VIII & -0.07 & 0.09 & 0.01 & -0.49 & 0.06 & 0.00 & $* * *$ & 0.07 & 0.03 & 0.18 & -0.41 & 0.01 & 0.09 & $* * *$ \\
\hline IX & -0.23 & 0.08 & 0.01 & -0.44 & 0.10 & 0.01 & $* * *$ & -0.05 & 0.03 & 0.19 & -0.35 & 0.01 & 0.08 & $\star \star * *$ \\
\hline$x$ & -0.47 & 0.07 & 0.01 & -0.61 & 0.10 & 0.01 & 0.0002 & -0.48 & 0.01 & 0.11 & -0.61 & 0.01 & 0.10 & $* * *$ \\
\hline$X I$ & -0.28 & 0.07 & 0.01 & -0.42 & 0.09 & 0.01 & $\star * *$ & -0.09 & 0.02 & 0.16 & -0.39 & 0.02 & 0.12 & $\star * *$ \\
\hline VL_IV & -0.40 & 0.09 & 0.01 & -0.34 & 0.06 & 0.00 & 0.0725 & -0.22 & 0.00 & 0.05 & -0.15 & 0.01 & 0.08 & 0.0002 \\
\hline
\end{tabular}

Appendix 2. Mean, standard deviations, and variance measures of the morphology of major males and minor males of $S$. platyrhinus. The result of T test for independent polyphenism in males is also shown. $\left.{ }^{* * *}\right)$ for $p \leqslant 0.0001$.

\begin{tabular}{|c|c|c|c|c|c|c|c|}
\hline \multirow{2}{*}{ Measures } & \multicolumn{3}{|c|}{ Major Males } & \multicolumn{3}{|c|}{ Minor Males } & \multirow{2}{*}{$T$ test } \\
\hline & Mean & Variance & SD & Mean & Variance & SD & \\
\hline RL1 & 4.17 & 0.43 & 0.65 & 2.67 & 0.45 & 0.67 & *** \\
\hline RAW & 1.78 & 0.05 & 0.21 & 1.37 & 0.04 & 0.19 & 0.0002 \\
\hline MW1R & 1.17 & 0.07 & 0.27 & 0.99 & 0.04 & 0.20 & 0.1450 \\
\hline MW2R & 2.29 & 0.15 & 0.38 & 1.60 & 0.10 & 0.31 & 0.0002 \\
\hline RBW & 2.74 & 0.13 & 0.36 & 1.94 & 0.16 & 0.39 & $* * *$ \\
\hline HW & 2.20 & 0.05 & 0.22 & 1.71 & 0.05 & 0.21 & $\star \star \star *$ \\
\hline $\mathrm{PL}$ & 2.21 & 0.05 & 0.23 & 1.79 & 0.07 & 0.26 & 0.0002 \\
\hline PW & 2.59 & 0.06 & 0.24 & 2.06 & 0.10 & 0.32 & $\star * *$ \\
\hline EL & 4.88 & 0.16 & 0.40 & 3.92 & 0.20 & 0.45 & $\star * *$ \\
\hline EW & 2.86 & 0.08 & 0.28 & 2.29 & 0.14 & 0.37 & $\star * \star$ \\
\hline MEW & 0.99 & 0.01 & 0.11 & 0.87 & 0.01 & 0.10 & 0.0109 \\
\hline DIS & 1.50 & 0.16 & 0.40 & 1.06 & 0.07 & 0.26 & 0.0108 \\
\hline IEW & 1.41 & 0.03 & 0.17 & 1.02 & 0.03 & 0.18 & $* * *$ \\
\hline II & 0.31 & 0.01 & 0.11 & 0.24 & 0.00 & 0.05 & 0.0181 \\
\hline III & 1.01 & 0.05 & 0.23 & 0.77 & 0.02 & 0.14 & 0.0195 \\
\hline
\end{tabular}


Appendix 2. Continued.

\begin{tabular}{|c|c|c|c|c|c|c|c|}
\hline \multirow{2}{*}{ Measures } & \multicolumn{3}{|c|}{ Major Males } & \multicolumn{3}{|c|}{ Minor Males } & \multirow{2}{*}{$\mathrm{T}$ test } \\
\hline & Mean & Variance & SD & Mean & Variance & SD & \\
\hline IV & 1.19 & 0.04 & 0.19 & 0.87 & 0.05 & 0.23 & 0.0013 \\
\hline V & 1.30 & 0.02 & 0.14 & 0.94 & 0.05 & 0.23 & $\star \star * *$ \\
\hline VI & 1.25 & 0.01 & 0.09 & 0.91 & 0.05 & 0.23 & $* * *$ \\
\hline VII & 1.15 & 0.01 & 0.09 & 0.86 & 0.04 & 0.19 & $\star \star \star *$ \\
\hline VIII & 0.96 & 0.01 & 0.11 & 0.73 & 0.02 & 0.14 & $* * *$ \\
\hline IX & 0.63 & 0.01 & 0.10 & 0.52 & 0.01 & 0.09 & 0.0129 \\
\hline$x$ & 0.36 & 0.00 & 0.06 & 0.32 & 0.00 & 0.04 & 0.2229 \\
\hline XI & 0.57 & 0.01 & 0.08 & 0.48 & 0.01 & 0.08 & 0.0132 \\
\hline VL_IV & 0.44 & 0.01 & 0.07 & 0.34 & 0.00 & 0.05 & 0.0011 \\
\hline VL_V & 0.47 & 0.01 & 0.11 & 0.40 & 0.01 & 0.07 & 0.0460 \\
\hline
\end{tabular}

Submitted: 05.IV.2013; Accepted: 22.XII.2013.

Editorial responsibility: Gabriel L.F. Mejdalani 